Volume 6, Issue 4, 475 - 484.

ISSN: $2165-8714$

http://www.eu-jer.com/

\title{
Do Job Satisfaction and Demographic Characteristics of Female Teachers influence their Affective Commitment to Schools?
}

\author{
M. Sait Dinc * \\ International Burch University, BOSNIA AND HERZEGOVINA
}

\author{
Zubeyde Kocyigit \\ International Burch University, BOSNIA AND HERZEGOVINA
}

Received: July 14, 2017 - Revised: July 30, 2017 - Accepted: August 3, 2017

\begin{abstract}
The main purpose of this paper is to examine the effect of ethical leadership on teachers' job satisfaction, and affective commitment in an education sector. This study proposes that ethical leadership has a significant and positive effect on overall job satisfaction and affective commitment. Moreover, it suggests that ethical leadership has an influence on overall job satisfaction and affective commitment. In this study, the relationships among the variables were evaluated using correlation, and regression analysis. The results which is based on a sample of 150 teachers from four private schools in Pakistan demonstrate that overall job satisfaction has a significant and positive influence on affective commitment, whereas, marriage as a demographic variable has a positive effect on overall job satisfaction and affective commitment.
\end{abstract}

Keywords: Ethical leadership, job satisfaction, affective commitment, private primary schools, female teachers, demographic characteristics.

To cite this article: Dinc, M. S., \& Kocyigit, Z. (2017). Do Job Satisfaction and Demographic Characteristics of Female Teachers influence their Affective Commitment to Schools? European Journal of Educational Research, 6(4), 475-484. doi: 10.12973/eujer.6.4.475

\section{Introduction}

The most important particle that constitutes a social life is human beings. Human beings are inevitably valuable and important for all organizations. Educational organizations, in particular, have an important role in the development of a society. Teachers are the most significant human resources in these educational institutions. Performance of teachers is directly related to the performance of their schools and students. Therefore, school administrations always wish to retain quality and high performing teachers in their institutions. Many studies in the organizational behavior have demonstrated that organizational commitment, particularly, affective commitment, is positively and significantly related to employees' performance (Dinc \& Plakalovic, 2016; Meyer \& Allen, 1997; Tourigny, Baba, Han, \& Wang, 2013).

Affective commitment is an individual's emotional attachment to the organization. Employees who have a strong affective commitment remain with the organization because they wish to (Meyer, Allen \& Smith, 1993). However, job satisfaction and organizational commitment are frequently examined together. Several studies indicated that job satisfaction has a large positive effect on commitment of employees to their organization (Fu \& Despande, 2014; Huang, You \& Tsai, 2012). Namely, employees who are satisfied with their job are more likely to remain with their organizations. There are many factors which influence job satisfaction and organizational commitment of employees in these organizations. One of the most important factors is ethical leadership behaviors of managers. Managers who show higher levels of ethical leadership decrease unethical behaviors and influence subordinate attitudes. Ethical leadership can specifically increase the follower satisfaction with the leader and organizational commitment (Mayer, Aquino, Greenbaum \& Kuenzi, 2012). However, marital status has been found as a consistent predictor of employees' attitudes, particularly, organizational commitment. In a specific sense, married people are more committed to their organization than unmarried people (John \& Taylor, 1999). While there is an abundance of studies that have explored the relationship between ethical leadership, employees' job satisfaction, and organizational commitment in developed countries, literature focusing on the aforementioned relationship in the context of developing countries is severely limited.

Pakistan is one of these developing countries in South Asia. It is in the sixth place with respect to world population. When compared to other countries in the region, Pakistan's performance is weak on the health and education related elements of competitiveness. The education system of Pakistan is comprised of 303,446 institutions and it is facilitating

* Corresponding author:

M. Sait Dinc, International Burch University, Department of Management, Bosnia and Herzegovina

Email: m.sait.dinc@ibu.edu.ba 
$47,491,260$ students with the help of 1,723,790 teachers. $37 \%$ of private educational institutions are serving $42 \%$ of students, which hints at a slightly higher per-institution enrollment ratio in the private sector in comparison to the public sector. In the last decade, public interest and trust in the private sector has increased, with the result that the share of private sector is increasing gradually. It is considered that the public sector of education has a deficiency in the number of teaching staff as compared to a private sector. The overall education system is served by $41 \%$ of male teachers and 59\% of female teachers." (Information about Pakistan, 2016). In this regard, performance of female teachers, and the factors such as affective commitment and job satisfaction that affect performance in private primary schools are vital. However, the role of the managers in each school has a strong influence on whether teachers show commitment to schools.

Overall, this research examines the effect of ethical leadership behaviors of school principals along with the demographic characteristics on female teachers' job satisfaction and affective commitment to the organization in private schools in Pakistan. As it was illustrated in the research model (see Figure 1), this study uses path analysis. The model entails two paths that includes some regression analyses. The first path investigates the relationship between ethical leadership, demographic variables, and overall job satisfaction. The second path explores the relationship between ethical leadership, overall job satisfaction, demographic variables and affective commitment.

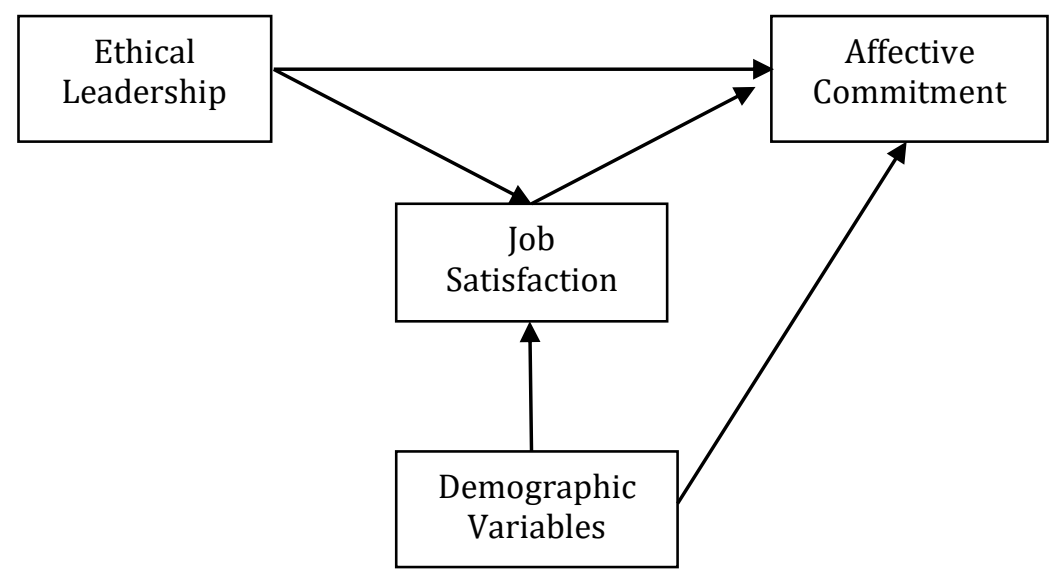

Figure 1. Proposed Model of the Study

\section{Ethical Leadership}

Leaders have a responsibility to set a standard for the members of the organization and to define those actions which may be aligned to the principles of society in overall (Aronson, 2001). Ethical behavior of leaders refers to the action of leaders when they are performing what is ethically right, fair, and respectable, as well as when they aid in raising organizational members' moral awareness and moral self-actualization. Ethical leadership may be defined as "the demonstration of normatively appropriate conduct through personal actions and interpersonal relationships, and the promotion of such conduct to followers through two-way communication, reinforcement, and decision-making" (Brown, Trevino, \& Harrison, 2005, p. 120). In a definition, ethical leaders are defined as "those who demonstrate ethical behavior, take into account the wishes of the people, act impartially and without prejudice, and advocate fairly the rights of employees" (Zhu, May, \& Avolio, 2004, p. 18). In these definitions, it can be noticed that ethical leaders have some basic features such as honesty, ethical awareness, collective-human orientation, ethical responsibility, motivation, encouragement, and empowerment (Resick, Hanges, Dickson, \& Mitchelson, 2006).

Ciulla (1995) discussed that leadership studies should be based on ethics. Specifically, it represents an ethical behavior of leaders that may help us set a standard to differentiate an effective from an ineffective leadership. Moreover, Northouse (2010) proposed the same idea that ethics forms a base to leadership, quoting the impact of leader influence, association with followers, and foundation of organizational values. Ethical leadership style represents a leader who can enhance employees' outcomes (Brown \& Mitchell, 2010).

There is a consistency between words and behaviors of ethical leaders. Ethical leaders are prominent because of their veracity and humane motivation. In addition to their role and position in the organizations, they are also perceived as credible. Their strength to shape the behavior enhances the efficacy of the behavior modeling process (Kouzes \& Posner, 2008).

Ethical leadership incorporates more than the promotion of the ethical behaviors. For instance, Butcher (1997) discussed that ethical leaders need not only put in the small trees and experimental hybrids that may not show a result 
in near future or afterwards, but they are also concerned for the soil that lets us produce in the first place (p. 5-6). Therefore, ethical leaders should foster the favorable environment and organizational culture for ethical behavior in members of the organization. Ethical leaders use dimensions from both distributive and procedural justice to shape their behaviors and treat employees in a balanced, rational, and just way. This behavior ultimately impacts job attitudes, satisfaction level, commitment, and organizational outcomes (Dailey \& Kirk, 1992; Koh \& Boo, 2001; Hassan, Wright, \& Yukl, 2014). Tansky, Gallagher, and Wetzel (1997) also discussed the perception of justice and equity impact as employees' approaches to their organization. For instance, strong personal ethical standards encourage a higher level of loyalty and trust in an organization. However, as leadership is a persuasive mechanism (Ciulla, 1995; Yukl, 2002), and achievement of the organizational goals are greatly reliant on how a leader motivates the members to enhance their performance in the organization. A leader's ability to impact employees' attitudes and behaviors can be quantified by several factors, such as employees' job performance, job involvement, job satisfaction, organizational citizenship behavior, and organizational commitment (Daft, 2004; McShane \& Von Glinow, 2010).

\section{Affective Commitment}

Organizational commitment has been defined in the literature as a comparative strength of an individual's identification and involvement in a particular organization (Mowday, Porter \& Steers., 1982, p. 27). The factors leading to organizational commitment can be categorized into three areas, such as organizational factors, personal factors, and work experiences (Eby, Freeman, Rush, \& Lance, 1999;). For instance, Mowday et al. (1982) discussed that supervision is one of the major organizational factors that can have an impact on employees' commitment to the organization. Studies support the notion that comprehension of individual, group, and organizational processes which are related to the organizational commitment has major inferences for employees, organizations, and society (Conger, 1999).

It has been discussed in previous studies that commitment creates a give-and-take relationship in which the members of the organization attach themselves to the organization expecting some rewards (Buchanan, 1974). Individuals join the organization with some expertise and special requirements in their minds. Afterwards, they search for a conducive environment where they can use their expertise and fulfill their requirements. When an organization can provide these opportunities, the possibility of enhanced commitment is increased.

Previous studies have demonstrated a strong relationship between organizational commitment and leadership behaviors, as organizational commitment is greater for employees whose leaders support their participation in decision-making (e.g., Jermier \& Berkes, 1979; Rhodes \& Steers, 1981), who indulge them with contemplation (e.g., Bycio, Hackett, \& Allen, 1995; DeCotiis \& Summers, 1987) and justice (e.g., Allen \& Meyer, 1990), and stand by them (e.g., Allen \& Meyer, 1990; Mottaz, 1988; Withey, 1988). It is probable that leaders who demonstrate ethical behaviors are more concerned and responsive to individual and group needs and treat them with justice.

Mize (2000) also concluded that there is a positive relationship between ethical behavior of leaders and employees' commitment level. When the leaders of the organization are viewed as having adopted advice-giving or participative behavior where shared decision-making is predominant, commitment to the organization is likely enhanced and employees' performance will be better (Yousef, 2000).

Organizational commitment and job satisfaction are some of the key factors in the success of every organization. Higher levels of organizational commitment and job satisfaction bring about higher levels of devotion to reach organizational goals, which is closely associated with organizational effectiveness (Dee et al., 2006). The education sector seems to be reliant on the way the teachers feel about their work and how satisfied they are with it. Researchers suggest that "schools must give more attention to increasing teacher job satisfaction" (Heller, Clay, \& Perkins, 1993, p. 75). Literature supports that job satisfaction is positively correlated with decision making and transformational leadership (e.g., Maeroff, 1988; Rossmiller, 1992). In overall, studies suggest that teaching staff reports higher satisfaction in their work when they perceive their school principal as someone who shares information with others, delegates authority, and find some channels to communicate with the teachers.

On the other hand, commitment model is classified in the literature with terms, such as 'affective', 'continuance' and 'normative' by Meyer \& Allen (1990). Affective commitment is an individual's emotional attachment to the organization. According to Meyer et al. (1993), employees who have a strong affective commitment stay with the organization because they wish to. Meyer and Allen (1997) have argued that both normative commitment and affective commitment will be linked to performance, however, affective commitment is more related to it.

In this study, affective commitment of the organizational commitment is selected because of women population of the study in Pakistan. The study expects that teacher's job satisfaction will have a significant effect on their affective commitment.

\section{Job Satisfaction}

Job satisfaction has generally been defined in literature as an employee's affective reaction to a job based on a variety of elements (Fields, 2002). Job satisfaction is generally featured as a manifold variable that combines employees' approach towards a variety of both intrinsic and extrinsic job elements. It incorporates satisfaction related to salary, 
benefits, promotion, work environment, supervision, organizational practices, and relationship with co-workers (Misener et al., 1996).

Leadership has been viewed as an important and primary antecedent to job satisfaction. As leadership is mostly directed towards people and social interaction, it is also considered as the process of affecting people so that they reach the organizational goals (Skansi, 2000). Studies have shown that there has been a significant association between job satisfaction and supervisory communication (Blegen, 1993), and leader relations (Irvine \& Evans 1995). Literature also supports that job satisfaction is positively associated with a participative decision making and transformational leadership (e.g., Maeroff, 1988; Rossmiller, 1992).

Research studies conducted in education sector have depicted that the school principals' behavior has an impact on teachers' job satisfaction (Bogler, 2001; Dinham \& Scott, 2000). For instance, Maeroff (1988) has discussed that job satisfaction is strongly and positively associated with participative decision-making. It was reported that teachers have greater satisfaction in their job when they see their school principal as someone who shares information, gives authority, and is communicative with them. Morris and Sherman (1981) suggested that strong school principal leadership is a consistent factor that affects teachers' job satisfaction and motivation. Drawing on this literature, the following hypotheses are posited:

Hypothesis 1: Ethical leadership has a positive effect on overall job satisfaction.

Hypothesis 2: Ethical leadership has a positive effect on affective commitment.

Hypothesis 3: Overall job satisfaction influences affective commitment

Hypothesis 4: Demographic variables have a positive effect on overall job satisfaction and affective commitment.

\section{Research method}

\section{Sample and data collection}

A federal parliamentary republic state, Pakistan is a federation that includes four provinces: Punjab, KhyberPakhtunkhwa, Sindh, and Balochistan and four territories. Islamabad is the capital territory. Lahore, Peshawar, Karachi, and Quetta are the capital cities of those provinces. Today most population of the country lives in Islamabad, Lahore, Karachi, and Peshawar respectively. In order to ensure the generalization of the research results, this research targeted female private primary school teachers in Islamabad, Lahore, and Karachi. Because number of female teachers working in private primary schools in Pakistan is 81.435 which is $82 \%$ of total number of teachers (Information about Pakistan, 2016). Four private primary schools (two from Islamabad and one from Lahore and Karachi) were selected randomly. 823 female teachers were working in selected schools. 55 questionnaires were distributed in each school, resulting in a total possible sample of 220 teachers. This study distributed 220 questionnaires constituting about 1/40 of the teachers' population. There are 150 validity questionnaires of this study, which represent the effectiveness of the study.

Formal research approval was obtained from the administration of each study school. Questionnaires and the explanation of the study's purpose were sent to the school administration that agreed to participate in the study. Through administrative staff, these questionnaires were distributed to teachers who volunteered to participate in the study. After completion of the questionnaire, the staff collected the questionnaires from the teachers. A total of 150 respondents (The overall response rate was 68\%.) returned the survey and all of them were useable for this study.

A summary of the sample characteristics is presented in Table 1. All participants were females. $48.7 \%$ of these teachers were between 26-30 years old. Predominant education of the teachers $(68.7 \%)$ was master level. The majority (62.7\%) was earning between 200 and 400 USD. In total, $68 \%$ of the teachers' total work experience was between 5 and 10 years. 
Table 1. Sample Characteristics

\begin{tabular}{|c|c|c|c|}
\hline Variable & Demographics & Number & Valid Percent \\
\hline \multirow[t]{4}{*}{ Age } & Under 20 years & 5 & 3.3 \\
\hline & 21-25 years & 29 & 19.3 \\
\hline & $26-30$ years & 73 & 48.7 \\
\hline & $31-35$ years & 43 & 28.7 \\
\hline \multirow[t]{2}{*}{ Marriage } & Yes & 63 & 42 \\
\hline & No & 87 & 58 \\
\hline \multirow[t]{3}{*}{ Job Experience (in school) } & Under 5 years & 50 & 33.3 \\
\hline & $5-10$ years & 86 & 57.3 \\
\hline & $10-15$ years & 14 & 9.3 \\
\hline \multirow[t]{3}{*}{ Job Experience (Total) } & Under 5 years & 37 & 24.7 \\
\hline & $5-10$ years & 102 & 68 \\
\hline & $10-15$ years & 11 & 7.3 \\
\hline \multirow[t]{2}{*}{ Education Level } & Bachelor degree & 47 & 31.3 \\
\hline & Master degree & 103 & 68.7 \\
\hline \multirow[t]{3}{*}{ Income } & 0 - 200 USD & 1 & 0.7 \\
\hline & $200-400$ USD & 94 & 62.7 \\
\hline & $400-600$ USD & 55 & 36.7 \\
\hline
\end{tabular}

\section{Research design and measures}

A three-page questionnaire with four sections was used to collect data for this study. The first part of the questionnaire includes questions about ethical leadership. The respondents completed 10-item scale developed by Brown et al. (2005).

The second part of the questionnaire was related to job satisfaction. Job satisfaction was measured using three items developed by Fu and Deshpande (2013). They adapted three-item scale from Cellucci and Devries's (1978) job satisfaction scale. These three items were: "I frequently think about quitting this job" (reverse coded); "I am satisfied with the activities I perform every day;" "Generally speaking, I am very satisfied with this job.” The Cronbach's alpha coefficient for this scale in their study was 0.627.

The third part of the questionnaire included questions about affective commitment. The participants completed Meyer and Allen's (1997) six-item affective commitment scale. They were: "I would be very happy to spend the rest of my career with this organization;" "I really feel as if this organization's problems are my own;" "I do not feel a strong sense of belonging to my organization;" "I do not feel like "a part of the family" in my organization" (reverse coded); "I do not feel "emotionally attached" to this organization" (reverse coded); "This organization has a great deal of a personal meaning for me." The Cronbach's alpha coefficient for this scale in their study was 0.694 .

The last section of the questionnaire contained demographic questions, such as age, gender, education, income, and duration of teacher's employment in the private schools and total.

The survey was prepared in the English language, and a printed copy of the questionnaire was used while collecting data. In all scales, the questions were measured using a 5-point Likert scale, ranging from "1" (strongly disagree) to "5" (strongly agree).

\section{Data analysis}

The data were analyzed by using SPSS (v. 20) software packages. Exploratory factor analysis was used to analyze the initial factor structure. Reliability of the scales was measured by using Cronbach's alpha coefficient. General characteristics of participants were summarized after the analysis of descriptive statistics. Pearson's correlations were used to show the relationships between ethical leadership, overall job satisfaction, marriage, and affective commitment. Finally, this study uses path analysis which requires two paths that includes some Linear regression analyses. The first path explores the relationship between ethical leadership, marriage, and overall job satisfaction. The second path investigates the relationship between ethical leadership, overall job satisfaction, marriage and affective commitment.

\section{Results}

\section{Initial analyses}

The construct validity of three scales used in the analysis was checked using the exploratory factor analysis to analyze the initial factor structure (Churchill, 1979). The ethical leadership scale was analyzed first. The principal component analysis was used as the factor extraction method, and the varimax method was used for the component rotations. After three runs, items 2, 3, 5, 6, and 7 in this scale were removed from the further analysis. The items were removed 
due to their loadings that were lower than 0.4. Five meaningful items were obtained. The coefficient alpha for ethical leadership was 0.581 as shown in Table 2. Secondly, affective commitment and overall job satisfaction scales were analyzed together. After two runs, items 13 and 16 were removed from the affective commitment scale, because their loadings were lower than 0.4. Item 10 was also eliminated from the further analysis of affective commitment scale as it was cross-loaded on two components. Three meaningful items for affective commitment, and three items for job satisfaction were obtained. The coefficient alpha for affective commitment and overall job satisfaction was 0.694 and 0.627 respectively. Factor loadings and coefficient alpha for these two scales are presented in Table 3.

Table 2. Factor Loadings and Coefficient Alpha for Ethical Leadership

\begin{tabular}{lcc}
\hline \multicolumn{1}{c}{ Ethical Leadership } & Factor Loading & Cronbach's Alpha \\
\hline My principal asks what is the right thing to do when making decisions. & & 0.581 \\
My principal disciplines employees who violate ethical standards. & 0.659 \\
My principal has the best interest of employees in mind. & 0.602 \\
My principal sets an example of how to do things the right way in terms of & 0.482 \\
ethics. & 0.413 \\
My principal conducts their personal life in an ethical manner. & \\
\hline
\end{tabular}

Table 3. Factor Loadings and Coefficient Alpha for Affective Commitment and Job Satisfaction

\begin{tabular}{|c|c|c|}
\hline & Factor Loading & $\begin{array}{c}\text { Cronbach's } \\
\text { Alpha }\end{array}$ \\
\hline Affective Commitment & & 0.694 \\
\hline I really feel as if this school's problems are my own. & 0.825 & \\
\hline $\begin{array}{l}\text { I would be very happy to spend the rest of my career in this } \\
\text { school. }\end{array}$ & 0.814 & \\
\hline I do not feel like part of the family at my school. * & 0.681 & \\
\hline Job Satisfaction & & 0.627 \\
\hline Generally speaking, I am very satisfied with this job. & & \\
\hline I am satisfied with the activities I perform every day. & & \\
\hline I frequently think about quitting this job. & & \\
\hline
\end{tabular}

*Items are reverse coded

Descriptive statistics and correlations for components of Ethical leadership, Job satisfaction, Demographic Variables, and Affective Commitment

Table 4 presents the means, standard deviations, and correlations for the variables used in the study. Relationships exist among overall job satisfaction, demographic variables, and affective commitment. Respondents identified the presence of affective commitment (mean $=4.21$ ). It was followed by ethical leadership (mean $=4.18)$, and finally mean score of job satisfaction was 3.29 .

Table 4. Mean, standard deviations, and correlations

\begin{tabular}{|c|c|c|c|c|c|c|c|c|c|c|}
\hline Variables & Mean & SD & 1 & 2 & 3 & 4 & 5 & 6 & 7 & 8 \\
\hline 1. Ethical Leadership & 4.18 & 0.39 & 1 & & & & & & & \\
\hline 2. Overall Job satisfaction & 3.29 & 0.47 & 0.12 & 1 & & & & & & \\
\hline 3. Age & & & -0.01 & 0.04 & 1 & & & & & \\
\hline $\begin{array}{l}\text { 4. Job Experience (in } \\
\text { school) }\end{array}$ & & & 0.02 & 0.01 & $0.50^{* *}$ & 1 & & & & \\
\hline 5. Job Experience (Total) & & & 0.08 & -0.09 & $0.29 * *$ & $0.36^{* *}$ & 1 & & & \\
\hline 6. Income & & & -0.06 & -0.06 & $0.19^{*}$ & $0.35^{* *}$ & -0.11 & 1 & & \\
\hline 7. Marriage & & & 0.75 & 0.08 & $-0.33^{* *}$ & $-0.29 * *$ & $-0.22 * *$ & $-0.26^{* *}$ & 1 & \\
\hline 8. Affective Commitment & 4.21 & 0.46 & -0.06 & $0.17^{*}$ & 0.02 & -0.08 & -0.01 & -0.10 & $0.17^{*}$ & 1 \\
\hline
\end{tabular}

${ }^{*} \mathrm{p}<0.05 ;{ }^{* *} \mathrm{p}<0.01$

Hypotheses testing

The hypotheses were tested with regression analyses. The regression results reported in Tables 5 are based on composite scale scores which were standardized before regression analyses were conducted. The estimated variance inflation factor scores were lower than the threshold value which indicates that multicollinearity did not affect the 
regression results adversely. The first hypothesis stated that ethical leadership has a positive effect on overall job satisfaction. As it was shown in the table, ethical leadership did not affect overall job satisfaction. Therefore, hypothesis 1 is not supported. Second hypothesis stated that ethical leadership has a positive effect on affective commitment. The results in the study show that ethical leadership did not affect affective commitment. Therefore, hypothesis 2 is also not supported. The third hypothesis stated that overall job satisfaction influences affective commitment. The study findings demonstrate that overall job satisfaction has a significant and positive influence on affective commitment. As a result, hypothesis 3 is supported. The fourth hypothesis stated that demographic variables have a positive effect on overall job satisfaction and affective commitment. The results in the study show that since only marriage has a positive and significant effect on affective commitment, this hypothesis is not supported.

\section{Table 5, Path analysis of the relationship among ethical leadership, overall job satisfaction, demographic variables, and affective commitment}

\begin{tabular}{lcc}
\hline Variables & Overall Job Satisfaction & Affective Commitment \\
\hline Ethical Leadership & 0.144 & -0.112 \\
Overall Job Satisfaction & & $0.162^{*}$ \\
Age & 0.055 & 0.073 \\
Job Experience (in school) & 0.059 & -0.102 \\
Job Experience (Total) & -0.129 & 0.037 \\
Income & -0.088 & -0.033 \\
Marriage & 0.700 & $0.173^{*}$ \\
\hline
\end{tabular}

$* \mathrm{p}<0.05$

\section{Discussion and Conclusion}

In this study, affective commitment was a highly rated variable in private schools in Pakistan. This is consistent with Fu and Despande's (2014) findings which demonstrated that affective commitment was the most highly rated organizational commitment component in an organization. Affective commitment is the most important dimension of organizational commitment. Employees who have a strong affective commitment remain with the organization because they want to (Meyer et al., 1993) and show active and voluntary participation in line with the goals of the organization, and desire it to be permanent (Huselid, 1991). The reason is because they develop an emotional attachment to their organization, and they start considering themselves as a part of the organization. This result of the study is also in line with Hrebiniak and Alutto's (1972) study results which stated that females leave their organizations less frequently than males. However, these study results support recent research findings which were conducted at a university in Pakistan and presented that female teachers were more committed to their organizations (Islam et al., 2012).

One of the conclusions of this research is that female teachers' affective commitment was positively influenced by their job satisfaction. This result confirmed the findings of previous studies that there was a significant and positive relationship between affective commitment and job satisfaction (Bateman \& Strasser, 1984; Dinc \& Huric, 2016; Eby, 1999). Namely, employees with a high emotional bond to their job try to do their best, because they are feeling a strong emotional attachment to their organization and work. The study findings are consistent with the previous research results. In a study, which focused on data collected from 125 full-time teachers from 33 universities in the three major cities of Pakistan, it was found that job satisfaction of teachers is positively correlated with organizational commitment (Chughtai \& Zafar, 2006). These study findings imply that female teachers who are satisfied with their jobs are more likely to be committed to their schools.

Another consequence of this study is the effect of demographic factors. The study results show that only marriage from demographic variables has a positive effect on teachers' affective commitment. This finding is consistent with some study findings in the education sector (Islam et al., 2012). In the case of this result, it can be suggested that married female teachers have a stronger affective commitment to their organization. Because married people have more family responsibilities and are in need of more stability and security in their jobs, they are likely to be more committed to their current organization than their unmarried colleagues (Chughtai \& Zafar, 2006).

Finally, the study did not find any relationship between school principals' ethical leadership behaviors, and teachers' job satisfaction and affective commitment. In contrast to previous research findings, such a result may be due to the study context. Replacement of the school principals in the selected private schools several months before conducting the study may be shown as a reason for this result.

\section{Implications for Practice}

Taken together, the study findings highlight the importance of teachers' job satisfaction and give number of suggestions that private school administrations can positively influence teachers' satisfaction with their job. According to Smith et 
al. (1969), one of the most important ways to satisfy individuals is through satisfaction with salary, promotions, and coworkers. Thus, private school administration and board of trustees can enhance teachers' satisfaction by increasing their compensation packages. They can also try to enrich the job of teachers by giving them more freedom in choosing textbooks and determining the teaching methodology (Chughtai \& Zafar, 2006), as well as by giving teachers more constructive and positive feedback regarding their jobs (Sommer \& Kulkarni, 2012). Finally, they can give more trainings to teachers and encourage them to participate in administrative issues of schools in order to satisfy their jobs. Teachers who are satisfied with their jobs and committed to their schools will be more likely to increase the satisfaction and happiness of their students.

\section{Limitations of the Study}

There are some limitations in this study. First, the results found in this research come from a limited sample. Surveys with greater sample sizes may yield different results. Secondly, self-reported issue may be another limitation of this study. Thirdly, the study focused on only female teachers in private primary schools. Results with male and female teachers from public primary schools may be differ. Finally, the insufficient literature may be a constraint in this research. Further studies should add more variables, such as job satisfaction facets and other organizational commitment components.

\section{References}

Allen, N. J., \& Meyer, J. P. (1990). The measurement and antecedents of affective, continuance and normative commitment to the organization. Journal of Occupational and Organizational Psychology, 63(1), 1-18.

Bateman, T. S., \& Strasser, S. (1984). A longitudinal analysis of the antecedents of organizational commitment. Academy of management journal, 27(1), 95-112.

Buchanan, B. (1974). Building organizational commitment: The socialization of managers in work organizations. Administrative Science Quarterly, 19(4), 533-546.

Brown, M. E., \& Mitchell, M. S. (2010). Ethical and unethical leadership: Exploring new avenues for future research. Business Ethics Quarterly, 20(04), 583-616.

Brown, M. E., Treviño, L. K., \& Harrison, D. A. (2005). Ethical leadership: A social learning perspective for construct development and testing. Organizational behavior and human decision processes, 97(2), 117-134.

Butcher, W. C. (1997). The need for ethical leadership. Executive Speeches, 11, 83-86.

Bycio, P., Hackett, R. D., \& Allen, J. S. (1995). Further assessments of Bass's (1985) conceptualization of transactional and transformational leadership. Journal of Applied Psychology, 80(4), 468.

Chughtai, A. A., \& Zafar, S. (2006). Antecedents and Consequences of Organizational Commitment Among Pakistani University Teachers. Applied HRM Research, 11(1), 39-64.

Ciulla, J. B. (1995). Leadership ethics: Mapping the territory. Business Ethics Quarterly, 5(1), 5-28.

Conger, J. A. (1999). Charismatic and transformational leadership in organizations: An insider's perspective on these developing streams of research. The Leadership Quarterly, 10(2), 145-179.

Daft, R. L. (2004). Organization Theory and Design. Thomson South-western: Mason.

Daileyl, R. C., \& Kirk, D. J. (1992). Distributive and procedural justice as antecedents of job dissatisfaction and intent to turnover. Human Relations, 45(3), 305-317.

DeCotiis, T. A., \& Summers, T. P. (1987). A path analysis of a model of the antecedents and consequences of organizational commitment. Human Relations, 40(7), 445-470.

Dee, J. R., Henkin, A. B., \& Singleton, C. A. (2006). Organizational commitment of teachers in urban schools: Examining the effects of team structures. Urban Education, 41(6), 603-627.

Dinc, M. S., \& Plakalovic, V. (2016). Impact of Caring Climate, Job Satisfaction, and Affective Commitment on Employees' Performance in the Banking Sector of Bosnia and Herzegovina. Eurasian Journal of Business and Economics, 9(18), $1-16$.

Dinc, M. S., \& Huric, A. (2016). The impacts of ethical climate types on nurses' behaviors in Bosnia and Herzegovina. Nursing ethics. doi: 10.1177/0969733016638143

Eby, L. T., Freeman, D. M., Rush, M. C., \& Lance, C. E. (1999). Motivational bases of affective organizational commitment: A partial test of an integrative theoretical model. Journal of occupational and organizational psychology, 72(4), 463483. 
Fields, D. L. (2002). Taking the measure of work: A guide to validated scales for organizational research and diagnosis. Sage.

Fu, W., \& Deshpande, S. P. (2014). The impact of caring climate, Job satisfaction, and Organizational Commitment on Job Performance of Employees in A China's Insurance Company, Journal Business Ethics, 339-349.

Hassan, S., Wright, B. E., \& Yukl, G. (2014). Does ethical leadership matter in government? Effects on organizational commitment, absenteeism, and willingness to report ethical problems. Public Administration Review, 74(3), 333343.

Heller, H. W., Clay, R., \& Perkins, C. L. I. N. E. (1993). The relationship between teacher job satisfaction and principal leadership style. Journal of School Leadership, 3(1), 74-86.

Hrebiniak, L. G., \& Alutto, J. A. (1972). Personel and role relatad factors in the development of organizational commitment. Administrative Science Quarterly, 17 (4), 555-573.

Huselid, M. A., \& Day, N. E. (1991). Organizational commitment, job involvement, and turnover: A substantive and methodological analysis. Journal of Applied Psychology, 76(3), 380.

Information about Pakistan (2016). Retrieved from https://drive.google.com/file/d/0BxoGkSRBpDivSzVGNktwWEFXdzA/view

Irvine, D. M., \& Evans, M. G. (1995). Job satisfaction and turnover among nurses: integrating research findings across studies. Nursing research, 44(4), 246-253.

Islam, T., Ahmad, Z., Ahmed, I., Ahmad, A., Muhammad, S., \& Muhammad, S. K. (2012). Does compensation and demographical variable influence on teacher's commitment and job satisfaction? a study of university of the Punjab. Pakistan. International Journal of Business and Management, 7(4), 35.

Jermier, J. M., \& Berkes, L. J. (1979). Leader behavior in a police command bureaucracy: A closer look at the quasimilitary model. Administrative Science Quarterly, 1-23.

John, M. C., \& Taylor, W. T (1999). Leadership style, school climate and the institutional commitment of teachers. International Forum (InFo), 2(1), 25-57.

Koh, H. C., \& Boo, E. F. H. (2001). The link between organizational ethics and job satisfaction: A study of managers in Singapore. Journal of Business Ethics, 29(4), 309-324.

Kouzes, J. M., \& Posner, B. Z. (2012). LPI: Leadership practices inventory development planner. John Wiley \& Sons.

Kouzes, J. M., \& Posner, B. Z. (2008). A leader's legacy. John Wiley \& Sons.

Lattimore, M. S., \& Glinow, M. A. (2010). Organizational Behavior: Emerging Knowledge and Practice for the Real World. Boston: McGraw-Hill Irwin.

Mayer, D. M., Aquino, K., Greenbaum, R. L., \& Kuenzi, M. (2012). Who displays ethical leadership, and why does it matter? An examination of antecedents and consequences of ethical leadership. Academy of Management Journal, 55(1), 151-171.

Meyer, J. P. \& Allen, N. J. (1997). Commitment in the Workplace: Theory, Research and Application. CA: Thousand Oaks, Sage.

Meyer, J. P., Allen, N. J., \& Smith, C. A. (1993). Commitment to organizations and occupations: Extension and test of a three-component conceptualization. The Journal of Applied Psychology, 78(4), 538-551. doi: 10.1037/00219010.78.4.538

Misener, T. R., Haddock, K. S., Gleaton, J. U., \& Ajamieh, A. R. A. (1996). Toward an international measure of job satisfaction. Nursing research, 45(2), 87-91.

Mize, K. J., Stanforth, N., \& Johnson, C. (2000). Perceptions of retail supervisors' ethical behavior and front-line managers' organizational commitment. Clothing and Textiles Research Journal, 18(2), 100-110.

Mottaz, C. J. (1988). Determinants of organizational commitment. Human Relations, 41(6), 467-482.

Mowday, R. T., Porter, L. W., \& Steers, R. M. (1982). Employee-organization linkage. The psychology of commitment absenteeism, and turn over. London: Academic Press Inc.

Mowday, R. T., Steers, R. M., \& Porter, L. W. (1979). The measurement of organizational commitment. Journal of Vocational Behavior, 14(2), 224-247.

Northouse, P. G. (2011). Introduction to leadership: Concepts and practice. Sage. 
Porter, L. W., Steers, R. M., Mowday, R. T., \& Boulian, P. V. (1974). Organizational commitment, job satisfaction, and turnover among psychiatric technicians. Journal of Applied Psychology, 59(5), 603.

Resick, C. J., Hanges, P. J., Dickson, M. W., \& Mitchelson, J. K. (2006). A cross-cultural examination of the endorsement of ethical leadership. Journal of Business Ethics, 63(4), 345-359.

Rhodes, S. R., \& Steers, R. M. (1981). Conventional vs. worker-owned organizations. Human Relations, 34(12), 10131035.

Rossmiller, R. A. (1992). The secondary school principal and teachers' quality of work life. Educational Management \& Administration, 20(3), 132-146.

Smith, C.A., Kendall, L.M. and Hulin, C.L. (1969). The Measurement of Satisfaction in Work and Retirement: A Strategy for the Study of Attitudes. Chicago: Rand McNally.

Sommer, K. L., \& Kulkarni, M. (2012). Does constructive performance feedback improve citizenship intentions and job satisfaction? The roles of perceived opportunities for advancement, respect, and mood. Human Resource Development Quarterly, 23(20), 177-201.

Tansky, J. W., Gallagher, D. G., \& Wetzel, K. W. (1997). The effect of demographics, work status, and relative equity on organizational commitment: Looking among part-time workers. Canadian Journal of Administrative Sciences, 14(3), 315.

Tett, R. P., \& Meyer, J. P. (1993). Job satisfaction, organizational commitment, turnover intention, and turnover: path analyses based on meta-analytic findings. Personnel Psychology, 46(2), 259-293.

Tourigny, L., Baba, V. V., Han, J., \& Wang, X. (2013). Emotional exhaustion and job performance: the mediating role of organizational commitment. The International Journal of Human Resource Management, 24(3), 514-532.

Tsai, M., \& Huang, C. (2008). The Relationship among Ethical Climate Types, Facets of Job Satisfaction, and the three components of organizational commitment: a study of nurses in Taiwan. Journal of Business Ethics, 80, 565-581.

Yousef, D. A. (2000). Organizational commitment: A mediator of the relationships of leadership behavior with job satisfaction and performance in a non-western country. Journal of Managerial Psychology, 15(1), 6-24.

Yukl G (2002). Leadership in organizations (5th ed.). Upper Saddle River, NJ: Prentice-Hall.

Zhu, W., May, D. R., \& Avolio, B. J. (2004). The impact of ethical leadership behavior on employee outcomes: The roles of psychological empowerment and authenticity. Journal of Leadership \& Organizational Studies, 11(1), 16-26. 